\title{
Acanalonia conica (Say, 1830): A new alien planthopper species established in Hungary (Auchenorrhyncha: Fulgoroidea: Acanaloniidae)
}

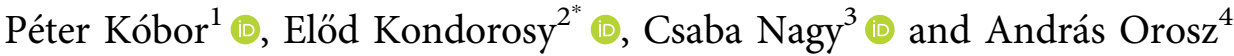

\footnotetext{
${ }^{1}$ Herman Ottó Institute Non-profit Ltd., Department of Nature Conservation and Ecology, H-1223, Budapest Park Street 2, Hungary

${ }^{2}$ Hungarian University of Agriculture and Life Sciences, Georgikon Campus, Department of Conservation Biology, Deák Ferenc Street 16, H-8360, Keszthely, Hungary

${ }^{3}$ Hungarian University of Agriculture and Life Sciences, Institute of Horticultural Science, Research Centre for Fruit Growing, Park Street 2, H-1223, Budapest, Hungary

${ }^{4}$ Hungarian Natural History Museum, Department of Zoology, Baross Street 13, H-1082, Budapest, Hungary
}

\section{RESEARCH ARTICLE}

Received:September 27,2021 • Revised manuscript received: October 20,2021 • Accepted: October 21, 2021

Published online: November 12, 2021

(C) 2021 The Author(s)

\section{ABSTRACT}

Acanalonia conica (Say, 1830), the first representative of the Nearctic planthopper family Acanaloniidae (Hemiptera: Auchenorrhyncha: Fulgoroidea), introduced to Europe, is reported for the first time from multiple locations in Hungary. Diagnosis, detailed illustration of male genitalia and notes on ecology are provided along with the distributional records.

\section{KEYWORDS}

Acanalonia conica, Fulgoromorpha, Acanaloniidae, new record, alien species

*Corresponding author. E-mail: kondorosy.ee@gmail.com 


\section{INTRODUCTION}

The genus Acanalonia Spinola (1839) consists of 60 valid taxa, most of them distributed in the Nearctic and Neotropical regions (Freund and Wilson, 1995; Gnezdilov, 2012). One of its representatives, Acanalonia conica (Say, 1830), was accidentally introduced and became established in Europe at the beginning of the $21^{\text {st }}$ century, now spreading rapidly. The taxon was first recorded in Veneto, Italy (D'Urso and Uliana, 2004, 2006) and became widespread throughout the country in the next years. More recently, its occurrence was reported from Switzerland (Trivellone et al., 2015), the southern part of Romania (Constantina et al., 2017), Slovenia (Seljak, 2018), Austria (Holzinger et al., 2020) and France (Pelozuelo et al., 2020). A. conica is known as a polyphagous herbivore, feeding on a variety of cultivated and wild plants belonging to different families, e.g. Rosaceae, Vitaceae, Asteraceae or Cannabaceae (Aldini et al., 2006; D'Urso and Uliana, 2006). The species is associated with flatid species Metcalfa pruinosa (Say, 1830), Anormenis chloris (Melichar, 1902) and Ormenoides venusta (Melichar, 1902) in America and is often found in mixed assemblages. This is resulted by the similar life history and overlapping distribution range of the four species (Wilson and Lucchi, 2001). A. conica is considered as a potential agricultural pest in viticulture because of inserting its eggs in wooden tissues of grapevine, causing mechanical damage in plant shoots, but currently, no report of serious damage is known. Hereby, the first occurrences of the species from Hungary are reported with morphological and ecological notes.

\section{MATERIAL AND METHODS}

Adults of A. conica were collected by Nikolett Farkas (1 male), Ottó Merkl (1 female), Csaba Nagy ( 1 female) and Tamás Zilay (1 male and 1 female) were deposited in the Hemiptera Collection of Hungarian Natural History Museum, Budapest (HNHM), personal collection of Előd Kondorosy (PCEK, Keszthely, Hungary) and Csaba Nagy (PCCN, Budapest, Hungary). Bibliography and current taxonomic names were acquired from the FLOW (Fulgoromorpha Lists on The Web) database (Bourgoin, 2021).

Distribution data was recorded in comma-delimited text (.csv) format in Microsoft Excel (2019) software. Processing and visualisation of the recorded data were performed with QGIS 3.4.14 "Madeira" geographic information system platform. Exoskeletal and genital structures were studied with Leica MZ 95 stereoscopic microscope. Measurements were done by calibrated ocular micrometre. Imaging was done with Nikon D7200 digital camera mounted with AF-S Micro Nikkor $105 \mathrm{~mm}$ 1:2.8 ED lens. Characters of male genitalia was illustrated by András Orosz. Morphological terminology was adapted from Freund and Wilson (1995).

\section{RESULTS}

Acanalonia conica (Say, 1830)

Diagnosis. Colouration greenish (colouration may fade to yellowish on dead insects) with pale brown and white decorations at margins of forewings; apical part of tibiae and tarsi brownish. Forewings conspicuously broadened. The species resembles to flatid planthoppers 
(e. g. M. pruinosa) in general facies, but with the combination of the following characters: in $A$. conica, veins of costal margin are irregular, in contrast in $M$. pruinosa, the veins of costal margin are parallel and perpendicular to the longitudinal axis of the body (Fig. 1); in A. conica surface of the clavus of forewing without tubercles contrary to $M$. pruinosa. Male genital structures as in Fig. 2.

Measurements of body length. male (HNHM): $8.76 \mathrm{~mm}$; females (HNHM): 9.77-10.1 mm.

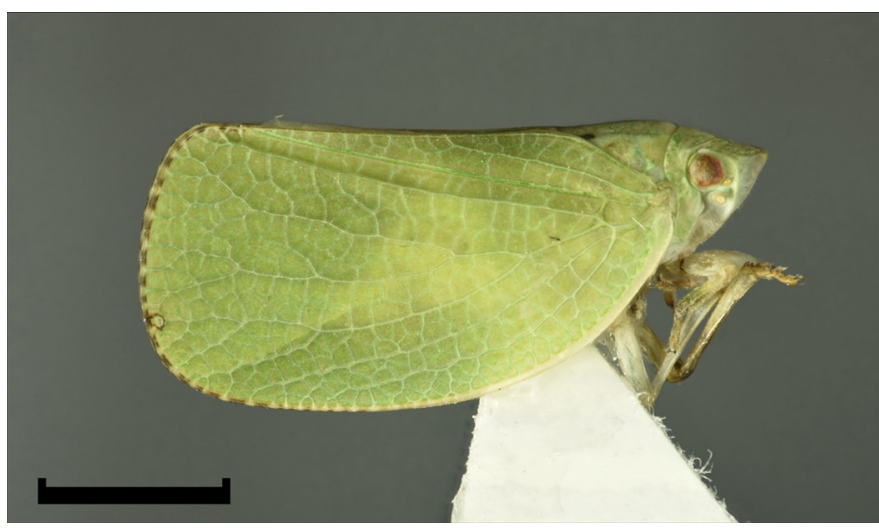

Fig. 1. Acanalonia conica (Say, 1830) lateral view (female, HNHM; scale bar: $3 \mathrm{~mm}$ )

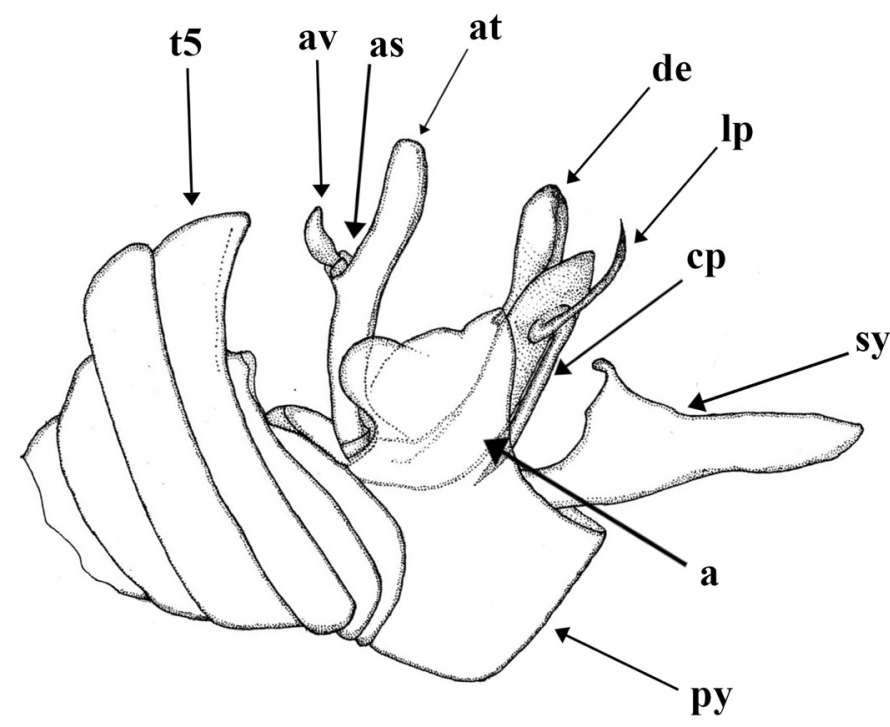

Fig. 2. Male genital apparatus of A. conica (lateral view; line drawing: A. Orosz) (Lettering: a - aedeagus; as - anal stylus; at - anal tube; av - anal valve; $\mathrm{cp}$ - caudal process; de - dorsal expansion; lp - lateral process; py - pygophore; sy - stylus; $\mathrm{t} 5$ - abdominal tergite V) 
Table 1. Occurences of A. conica in Hungary (asterisk indicates records at izeltlabuak.hu 2021 citizen science database and were based on visual observation and photos)

\begin{tabular}{|c|c|c|c|c|}
\hline Date & Location & GPS & Specimens & Collector (depository) \\
\hline August 2016 & $\begin{array}{c}\text { Alibánfa, Zala County, } \\
\text { Hungary }\end{array}$ & $\begin{array}{l}46^{\circ} 53^{\prime} \mathrm{N} \\
16^{\circ} 55^{\prime} \mathrm{E}\end{array}$ & 1 male & N. Farkas (PCEK) \\
\hline 09 August & Soroksár Botanical & $47^{\circ} 24^{\prime} \mathrm{N}$ & 1 female & O. Merkl (HNHM) \\
\hline 2018 & $\begin{array}{l}\text { Gardens, Budapest, Pest } \\
\text { County, Hungary }\end{array}$ & $1909^{\prime} \mathrm{E}$ & & \\
\hline $\begin{array}{l}22 \text { August } \\
2019\end{array}$ & $\begin{array}{c}\text { forest between Debrecen } \\
\text { and Pallag municipalities, } \\
\text { Hajdú-Bihar County, } \\
\text { Hungary }\end{array}$ & not available & $\begin{array}{l}1 \text { male, } \\
1 \text { female }\end{array}$ & T. Zilay (HNHM) \\
\hline $\begin{array}{l}30 \text { August } \\
2019\end{array}$ & $\begin{array}{c}\text { Újfehértó, Szabolcs- } \\
\text { Szatmár-Bereg County, } \\
\text { Hungary }\end{array}$ & $\begin{array}{l}47^{\circ} 82^{\prime} \mathrm{N} \\
21^{\circ} 67^{\prime} \mathrm{E}\end{array}$ & 1 female & Cs. Nagy (PCCN) \\
\hline $\begin{array}{l}21 \text { September } \\
2019\end{array}$ & $\begin{array}{c}\text { Budapest, Pest County, } \\
\text { Hungary }\end{array}$ & $\begin{array}{l}47^{\circ} 25^{\prime} \mathrm{N} \\
21^{\circ} 37^{\prime} \mathrm{E}\end{array}$ & $1 ?$ & $\begin{array}{l}\text { J. Mészáros (recorded by } \\
\text { B. Kókay) (izeltlabuak.hu } \\
\text { 2021) * }\end{array}$ \\
\hline 30 July 2021 & $\begin{array}{l}\text { Debrecen, Hajdú-Bihar } \\
\text { County, Hungary }\end{array}$ & $\begin{array}{l}47^{\circ} 31^{\prime} \mathrm{N} \\
21^{\circ} 37^{\prime} \mathrm{E}\end{array}$ & $1 ?$ & $\begin{array}{l}\text { Bodokrisz (izeltlabuak.hu } \\
\text { 2021) * }\end{array}$ \\
\hline
\end{tabular}

Findings in Hungary. Occurrences of A. conica were recorded from six locations in Hungary (Table 1, Fig. 3). Four records originate from collecting of specimens by sweep netting or singling (voucher specimens available in depositories as indicated in Table 1) and two records originate from visual observation of individuals with photo proof available at izeltlabuak.hu (2021) citizen science database.

Remarks. A. conica was thoroughly described in Freund and Wilson (1995). Larvae resemble those of Flatidae (e.g., M. pruinosa). Good quality habitus photo of larvae was published in Holzinger et al. (2020).

Ecology. In addition to the known European host plants listed by (Aldini et al., 2006; D’Urso and Uliana, 2006), we report the first recorded case of its feeding on Acer campestre, Humulus lupulus and Rubus fruticosus.

\section{DISCUSSION}

A. conica is the first representative of the Nearctic fulgoroid planthopper family Acanaloniidae, which was introduced and became established in Europe. Since its first report from Northeastern Italy, it appears to be spreading on the continent. Findings suggest that the species is present in Hungary since 2016, but in course of this 5-years period only sporadic occurrences of at most two individuals were recorded. Contrastingly, in the neighbouring countries (Austria, Romania and Slovenia) up to 12 specimens were originating from a single collecting site. Taking these data into account it is to be concluded that the understanding of the situation of $A$. conica in Hungary requires further, aimed monitoring of the species. The survey may imply citizen science approach due to the striking appearance and easy identification of the species. A. conica 


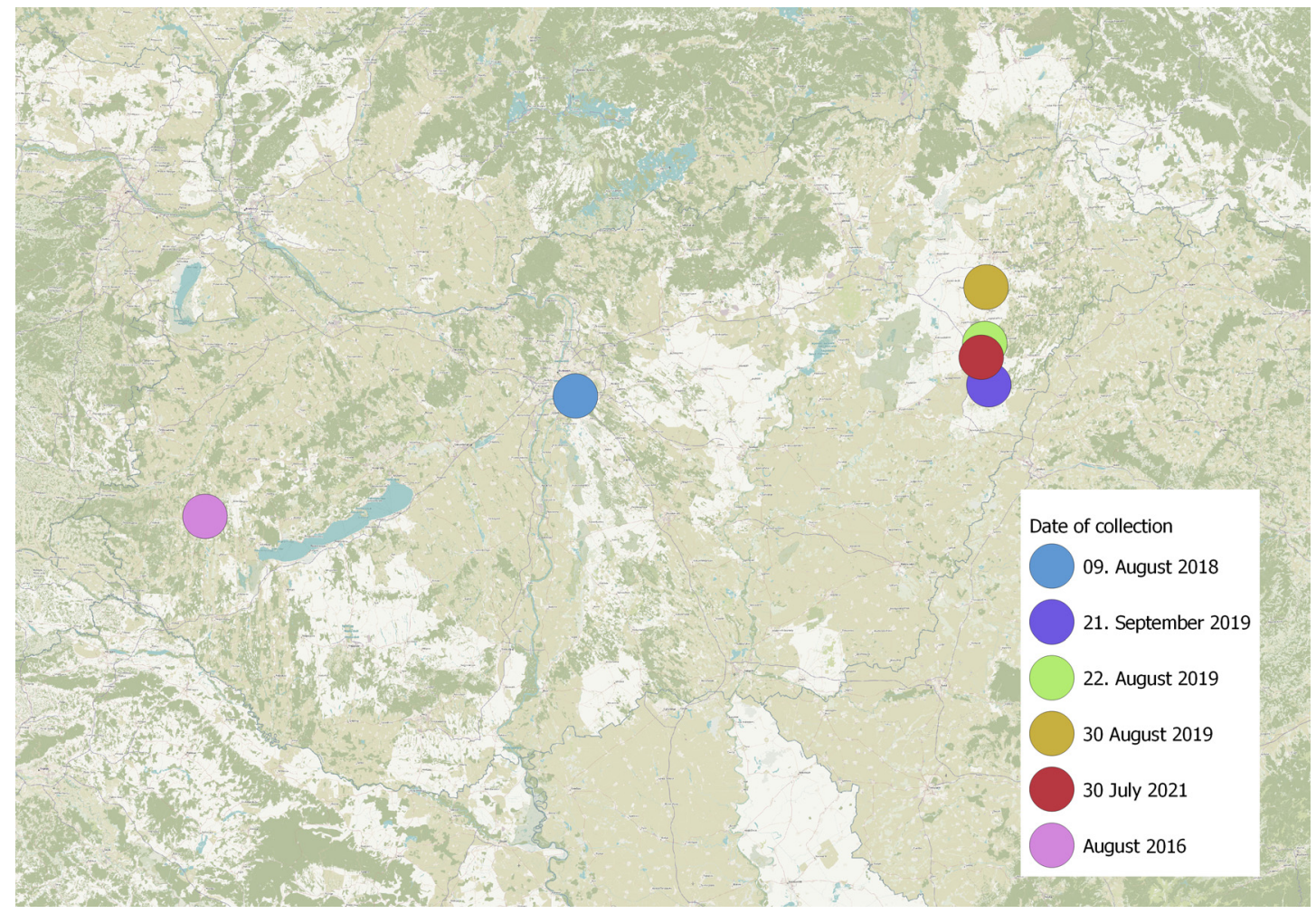

Fig. 3. Distribution of A. conica in Hungary (map generated with QGIS 3.4.14 „Madeira” software) 
can be readily distinguished from other planthopper taxa known from Hungary by its vivid greenish colouration combined with the conspicuously broadened forewing. The species resembles flatid planthoppers (e.g., M. pruinosa), but the differences in the venation of forewing and genital structures allow infallible identification. This planthopper species is a polyphagous herbivore with a relatively diverse host plant range which includes multiple cultivated plants of agricultural significance. The species is considered a potential pest of grapevines due to its oviposition behaviour: females inserting eggs in the wooden tissues of grapevine sprouts, thus causing mechanical damage. Furthermore, these scars can be entry points for bacterial, viral and fungal infections. A. conica is recorded to be forming mixed assemblages with three Nearctic flatid species, M. pruinosa, A. chloris and O. venusta, due to their overlapping area and host plant range. From these species, $M$. pruinosa is known from across Europe. The presence of $M$. pruinosa and A. conica on the continent suggests that in case of introduction, the remaining two species are likely to be established; thus, it is recommended to thoroughly monitor agricultural shipment containing host plants of these species.

\section{ACKNOWLEDGEMENTS}

The authors would like to express their gratitude to Nikolett Farkas, Tamás Zilay and Ottó Merkl (1957-2021) for the specimens collected. Furthermore, the authors would like to thank the work of the two anonymous reviewers for their comments and suggestions helping to improve the manuscript.

\section{REFERENCES}

Aldini, R.N., Mazzoni, E., and Ciampitti, M. (2006). Ritrovamento della cicalina neartica Acanalonia conica (Say) (Rhynchota: Fulgoromorpha: Acanaloniidae) in Lombardia (Italia settentrionale). Bollettino di Zoologia agrarian e di Bachicoltura, Serie II, 28(3): 261-264.

Bourgoin, T. (2021). FLOW (Fulgoromorpha Lists on The Web): a world knowledge base dedicated to Fulgoromorpha. Version 8, updated [2021-06-11]. Available at: https://hemiptera-databases.org/flow/ (Accessed 21 September 2021).

Constantina, C., Andrei, T., Minodora, G., Maria, D., and Paulina, A. (2017). Two new invasive hemipteran species first recorded in Romania: Orientus ishidae (Matsumura 1902) (Cicadellidae) and Acanalonia conica (Say 1830) (Acanaloniidae). Journal of Entomology and Zoology Studies, 5(2): 824-830.

D'Urso, V. and Uliana, M. (2004). First record of Acanalonia conica (Issidae) in Italy. In: Third european hemiptera congress, Abstracts, vol. 26. St. Petersburg: p. 27.

D’Urso, V., and Uliana, M. (2006). Acanalonia conica (Hemiptera, Fulgoromorpha, Acanaloniidae), a nearctic species recently introduced in Europe. Deutsche Entomologische Zeitschrift, 53(1): 103-107.

Freund, R. and Wilson, S. W. (1995). The planthopper genus Acanalonia in the United States (Homoptera: Issidae): male and female genitalic morphology. Insecta Mundi, 9(3-4): 195-216.

Gnezdilov, V. M. (2012). A new genus of the family Acanaloniidae (Homoptera: Fulgoroidea) from the Caribbean Basin. Zoosystematica Ross, 21(2): 302-305. 
Holzinger, W. E., Huber, E., Schlosser, L., and Kunz, G. (2020). Acanalonia conica (Say, 1830) and three other true hopper species new for Austria (Hemiptera: Auchenorrhyncha). Cicadina, 19: 9-19.

izeltlabuak.hu (2021). Acanalonia conica. Available at: https://www.izeltlabuak.hu/talalat/90210 (Accessed: 21 September 2021).

Melichar, L. (1902). Monographie der Acanaloniiden und Flatiden (Homoptera) (Fortsetzung). Annalen des k.k Naturhistorischen Hofmuseums, Wien, 17: 1-253.

Pelozuelo, L., Bourgoin, T., and Reynaud, P. (2020). A new alien species in France: first records of the green cone-headed planthopper Acanalonia conica (Say, 1830) (Hemiptera, Fulgoromorpha, Acanaloniidae). Bulletin de la Société entomologique de France, 125(4): 423-426.

Say T. (1830). Descriptions of new North American hemipterous insects, belonging to the first family of the section Homoptera of Latreille. Journal of the Academy of Natural Sciences of Philadelphia, 6: 235-244.

Seljak, G. (2018). Notable new findings of Auchenorrhyncha (Hemiptera) in Slovenia. Acta Entomologica Slovenica, 26(2): 181-194.

Spinola M. (1839). Essai sur les Fulgorelles, sous-tribu de la tribu des Cicadaires, ordre des Rhyngotes. (Suite). Annales de la Société Entomologique de France, 8: 339-454.

Trivellone, V., Knop, E., Turrini, T., Andrey, A., Humbert, J. Y., and Kunz, G. (2015). New and remarkable leafhoppers and planthoppers (Hemiptera: Auchenorrhyncha) from Switzerland. Mitteilungen der Schweizerischen Entomologischen Gesellschaft, 88: 273-284.

Wilson, S. W., and Lucchi, A. (2001). Distribution and ecology of Metcalfa pruinosa and associated planthoppers in North America (Homoptera: Fulgoroidea). Atti dell'Accademia nazionale Italiana di Entomologia. Rendiconti Anno, 49: 121-130.

Open Access. This is an open-access article distributed under the terms of the Creative Commons Attribution 4.0 International License (https://creativecommons.org/licenses/by/4.0/), which permits unrestricted use, distribution, and reproduction in any medium, provided the original author and source are credited, a link to the CC License is provided, and changes - if any - are indicated. (SID_1) 